\title{
Leaf anatomy of emerald grass submitted to quantitative application of herbicides
}

\author{
Anatomia foliar quantitativa de grama esmeralda submetida à \\ aplicação de herbicidas
}

\author{
Renata Pereira Marques ${ }^{1 *}$; Dagoberto Martins ${ }^{2}$; Roberto Antonio Rodella ${ }^{3}$; \\ Saulo Ítalo Almeida Costa ${ }^{4}$; Hermeson dos Santos Vitorino ${ }^{5}$
}

\begin{abstract}
The aim of this work was to evaluate the selectivity of herbicides applied in post-emergence on Zoysia japonica Steud (Poaceae) and determine associations with the leaf anatomy of this grass. The experimental design was randomized blocks with four replications. The treatments were the application of the herbicides bentazon ( $\left.720 \mathrm{~g} \mathrm{ha}^{-1}\right)$, nicosulfuron $\left(50 \mathrm{~g} \mathrm{ha}^{-1}\right)$, halosulfuron $\left(112.5 \mathrm{~g} \mathrm{ha}^{-1}\right)$, oxadiazon $\left(875 \mathrm{~g} \mathrm{ha}^{-1}\right)$ and 2.4-D $\left(698 \mathrm{~g} \mathrm{ha}^{-1}\right)$, plus a control treatment without herbicide application. Phytotoxicity was assessed every seven days after application (DAA) of the herbicides until the symptoms disappeared. Foliar anatomical analyses of the leaves in the collected grass were conducted until the $35^{\text {th }}$ DAA. The quantitative characters of the keel and wing region of the blade of Z. japonica were assessed, as well as the biometric characters, which were submitted to an analysis of variance $F$ test, and the averages were compared by Tukey's test at a probability of $5 \%$. The values of the anatomical characters of the foliar blade were tested by cluster analysis. The application of herbicides did not negatively influence the height of the plants but did reduce their dry mass. Toxic symptoms disappeared after 21 DAA, with the only symptoms of injury observed in plants treated with the herbicides oxadiazon and nicosulfuron. In addition, the cluster analysis indicated the formation of a unique discriminatory group. Thus, the results show that the herbicides applied to Z. japonica were selective for the species.
\end{abstract}

Key words: Plant anatomy. Lawns. Selectivity. Zoysia japonica.

\section{Resumo}

Objetivou-se com esse trabalho avaliar a seletividade de herbicidas aplicados em pós-emergência sobre grama Esmeralda - Zoysia japonica Steud (Poaceae), em associação com estudos da anatomia foliar dessa grama. O delineamento experimental foi em blocos ao acaso, com quatro repetições. Os tratamentos constituíram da aplicação dos herbicidas: bentazon $\left(720 \mathrm{~g} \mathrm{ha}^{-1}\right)$, nicosulfuron $\left(50 \mathrm{~g} \mathrm{ha}^{-1}\right)$, halosulfuron (112,5 $\left.\mathrm{g} \mathrm{ha}^{-1}\right)$, oxadiazon $\left(875 \mathrm{~g} \mathrm{ha}^{-1}\right)$ e 2,4-D $\left(698 \mathrm{~g} \mathrm{ha}^{-1}\right)$, além de um tratamento controle, sem aplicação de herbicidas. As avaliações de fitointoxicação foram realizadas a cada sete dias após a aplicação dos herbicidas (DAA) até o desaparecimento dos sintomas. Realizaram-se análises anatômicas foliares da grama coletando-se folhas no $35^{\circ} \mathrm{DAA}$. Avaliaram-se os caracteres quantitativos da região da quilha e da asa do limbo de $Z$. japonica, bem como os caracteres biométricos da grama, os quais foram

${ }^{1}$ Prof ${ }^{a} .$, Instituto Federal de Educação Ciência e Tecnologia Goiano, IF Goiano, Rio Verde, GO, Brasil. E-mail: renata.marques@ ifgoiano.edu.br

2 Prof., Universidade Estadual Paulista “Julio de Mesquita Filho”, UNESP/FCAV, Jaboticabal, SP, Brasil. E-mail: dmartins@fcav. unesp.br

3 Prof. Universidade Estadual Paulista “Julio de Mesquita Filho”, UNESP/IBB, Botucatu, SP, Brasil. E-mail: rodella@fca.unesp.br

${ }^{4}$ Pesquisador, Terracal Alimentos e Bioenergia, Guadalupe, PI, Brasil. E-mail: sauloagro@gmail.com

5 Prof., Universidade Estadual do Piauí, UESPI, Picos, PI, Brasil. E-mail: vitorinohermeson@gmail.com

* Author for correspondence 
submetidos à análise de variância pelo teste $\mathrm{F}$, e as médias comparadas pelo teste de Tukey a $5 \%$. Os valores dos caracteres anatômicos do limbo foliar foram submetidos ao teste de análise de agrupamento. A aplicação de herbicidas não influenciou negativamente a altura das plantas, porém reduziu massa seca. Os sintomas de fitointoxicação desapareceram até os 21 DAA, sendo que os únicos sintomas de injúrias foram observados nas plantas tratadas com os herbicidas nicosulfuron e oxadiazon. Além disso, a análise de agrupamento indicou a formação de um único grupo discriminatório. Desta forma, os resultados demonstram que os herbicidas aplicados sobre Z. japonica foram seletivos à espécie.

Palavras-chave: Anatomia vegetal. Gramados. Seletividade. Zoysia japonica.

\section{Introduction}

The main species of grass used in our country for establishing gardens and sports fields belong to the genera Axonopus, Cynodon, Paspalum, Stenotaphrum and Zoysia (KOJOROSKI-SILVA et al., 2011). Even with the appreciation of landscape works, research papers dealing with grass species are still incipient and the available information is more concentrated in the management of fertilization (GODOY et al., 2007). Information about the selectivity of herbicides is incipient because lawns have no agricultural importance, and concern about the selectivity of herbicides is in the background (MCELROY; MARTINS, 2013).

In regard to the presence of weeds in lawns, the difficulty of using chemical control defines the herbicide to be used because in Brazil, no herbicide is registered for use in lawn areas, making the management of weeds in the production and maintenance of lawns difficult (MAPA/AGROFIT, 2015). The use of non-selective herbicides can injure lawns and hinder the establishment of lawn areas, thus, lawns tend to have increasing problems with weeds (MONQUERO et al., 2012).

Weeds reduce the usability and aesthetic value of lawns, whether in homes, sports areas, parks or commercial lawns. The areas that are free of weeds increase the attractiveness of businesses and the value of properties. Regardless of the environment, weeds should not co-exist with contiguous areas of lawns. While it is possible to reduce the population of weeds using cultural or mechanical practices, this cannot eliminate them completely. The use of herbicides is the only way to completely control weeds in lawn areas (MCELROY; MARTINS, 2013).

The herbicide for use on lawns must be selective and must not cause injuries beyond the level of recovery in the plant of interest. For some authors, such as Souza et al. (2009), the selectivity of certain herbicides is more a question of the species, variety and dose applied rather than the product.

Leaf anatomical studies of herbicides applied to plants postemergence are useful in describing phytotoxicity symptoms (visual damage caused by herbicide application), contributing to the determination of the selectivity of herbicides, and allowing for the identification of susceptible biotypes tolerant or resistant to a given chemical.

As a possibility, herbicides that are used on crops, especially grasses, may have high potential for use in weed control in lawns. Bentazon, nicosulfuron, halosulfuron, oxadiazon and 2.4-D are examples of herbicides registered and used on lawn areas in countries, such as in the United States (GROSSMAN, 2009; BROSNAN et al., 2010; BHOWMIK, 2012; MCELROY; MARTINS, 2013).

Maciel et al. (2011) consider the use of selective herbicides and also promote the suppression of growth without sacrificing the visual quality of lawns. Thus, a need exists for studies that help control programs of weeds in lawns. Studies on the mechanisms of action, absorption and selectivity of herbicides can contribute to the list of safe-use molecules for lawns. The identification of leaf anatomical characteristics inherent in each type and descriptions of the toxic effects on leaf anatomy and morphology further complement the potentially selective herbicide recommendations. 
Therefore, we aimed to evaluate the selectivity of the herbicides bentazon, nicosulfuron, halosulfuron, oxadiazon and 2.4-D applied post-emergence onto Zoysia japonica Steud. (Emerald grass) and associate the selectivity of these herbicides with the leaf anatomy of this species of grass.

\section{Materials and Methods}

This study was conducted in two phases. The first phase was carried out under field conditions in the experimental area of the Faculdade de Ciências Agronômicas in Botucatu for the visual analysis of the effects of biometric herbicides and features. The second phase was held at the Anatomy Laboratory and Plant Morphology of Instituto de Bociências de Botucatu, which carried out the analysis of the anatomical characters of the leaf blade of this type of grass.

Used the grass species Z. japonica Steud. (Emerald grass) at 48 months of age and subjected it to the application of herbicides. A week before the application of the treatments, the lawn area was trimmed to a height of $3 \mathrm{~cm}$.

The experimental design was randomized blocks (DBC) consisting of six treatments with four replications. The experimental plots consisted of an area $2^{\prime} 2 \mathrm{~m}$.

The chemical treatments were bentazon $(720 \mathrm{~g}$ $\left.\mathrm{ha}^{-1}\right)$, nicosulfuron (50 $\left.\mathrm{g} \mathrm{ha}^{-1}\right)$, halosulfuron (112.5 $\mathrm{g} \mathrm{ha}^{-1}$ ), oxadiazon (875 $\mathrm{g} \mathrm{ha}^{-1}$ ) and 2.4-D (698 $\mathrm{g} \mathrm{ha}^{-}$ $\left.{ }^{1}\right)$ without the addition of adjuvants to prepare the syrup, and a control treatment without herbicide application.

The herbicides were applied post-emergence using a knapsack sprayer and a pressurized $\mathrm{CO}_{2}$ sprayer equipped with a 2-liter reservoir. The machine was set to provide a solution output of 250 $\mathrm{L} \mathrm{ha}^{-1}$. The application bar was equipped with five spray nozzles of the jet type "Teejet" DG 11002 , spaced $50 \mathrm{~cm}$ apart with a working pressure of 25 $\mathrm{lb} / \mathrm{in}^{2}$. At the time of application, the temperature was $25{ }^{\circ} \mathrm{C}$, the wind speed was $6 \mathrm{~km} / \mathrm{h}$, and the relative humidity was $75 \%$.

The phytotoxicity assessments of the species of grass were performed every 7 days after herbicide application (DAA) until the symptoms had disappeared following the methodology proposed by the Sociedade Brasileira da Ciência das Plantas Daninhas (1995).

A biometric analysis of the plants (plant height and dry mass) was conducted to measure the height of the Emerald grass plants (from the ground to the apex of the larger leaf). In total, 10 plants were sampled and measured with a ruler graduated in centimeters. At the end of the experimental period, the total dry matter produced by the treatments was determined by collecting the vegetal mass in $1 \mathrm{~m}^{2}$ plots. After drying in a forced-air oven at $65{ }^{\circ} \mathrm{C}$, the material was weighed on a precision scale.

To analyze the leaf anatomy of the Emerald grass, leaf material was sampled at random portions, and the fully expanded leaves were collected on the $35^{\text {th }}$ day after herbicide application.

Portions of the middle third of the leaf blade were taken, fixed in FAA 50 (formaldehyde + glacial acetic acid $+50 \%$ alcohol) for 48 hours and subsequently, stored in $70 \%$ ethanol (JOHANSEN, 1940). Four replications were made.

After fixation, the leaf samples were dehydrated in an ascending ethanol series and then infiltrated in glycol methacrylate resin (GERRITS, 1991). Cross sections were made with thicknesses of 4 to 8 micrometers using a rotary microtome, and the sections were stained with $0.05 \%$ Toluidine Blue (O'BRIEN et al., 1964) and mounted on "Permount "synthetic resin.

Microscopic observations of the anatomical structures of the midrib regions were subsequently made of the (keel) and the region between the midrib and the edge of the blade (wing) (METCALFE, 1960). The material was photomicrographed with its limits and contours of tissue measured with Cell^ ${ }^{\wedge}$ Olympus software. 
The anatomical structures present in the leaf surface were quantified from the ratio of the measured traits of the keel and wing regions. We quantified the percentage of the epidermis of the adaxial and abaxial surfaces, vascular bundle, vascular bundle sheath, sclerenchyma, and parenchyma with respect to the total area of the tissue measured in the assessed region. We also measured the distance between the bundles in the wing area, the leaf thickness, and the number of bundles in the leaf structure, counting the first bundle of the keel to the second largest existing bundle along the wing.

The percentages and weight data were tested for normality with the Shapiro-Wilk test and Bartlett's test for homogeneity of variance, and then transformed into $\arcsin \mathrm{X} / 100$ and $\mathrm{X}+1$, respectively. The results for the percentage phytotoxicity and dry mass of shoots were subsequently subjected to analysis of variance, and the treatment means were compared by Tukey's test using a 5\% probability $(\mathrm{p}>0.05)$ (PIMENTEL-GOMES, 1976).

The mean values of 15 quantitative leaf anatomical features of the keel area and Emerald grass wing after treatment with the herbicides were subjected to a multivariate analysis consisting of a statistical cluster analysis (SNEATH; SOKAL, 1973); the treatment means were compared by Tukey's test using a 5\% probability ( $p>0.05)$ (PIMENTEL-GOMES, 1976).

A cluster analysis was performed with the data transformed into percentages, using the Euclidean distance average for all indicators (ROHLF, 1992) with the UPGMA algorithm (unweighted pairgroup method with arithmetic average) to group the treatments according to their degree of similarity; the results of the analysis are presented as a dendrogram.

\section{Results and Discussion}

The herbicides applied post-emergence on $Z$. japonica cause up to $20 \%$ fewer injuries than in other plants. At 7 DAA, only halosulfuron and 2.4$\mathrm{D}$ did not cause symptoms of injuries in this type of grass, which were observed for injuries on the order of $4.88 \%, 9.53 \%$ and $15.75 \%$ for bentazon, nicosulfuron and oxadiazon, respectively. The symptoms of herbicide intoxication observed at 14 DAA were evident on the plants treated with nicosulfuron and oxadiazon (11.78\% and $10.25 \%$, respectively). At 21 DAA, only plants subjected to oxadiazon application had symptoms of injuries (2.85\%), and at 28 DAA, all plants had completely recovered (Table 1).

The herbicides used in this study were selective for Z. japonica and did not reduce coverage; only temporary discoloration occurred, which does not imply damage to the lawn (COSTA et al., 2010a). The observed tolerance could be due to the narrow and short morphology of the Emerald grass leaves, which causes the retention of herbicides (CHRISTOFFOLETI; ARANDA, 2001). Similar results were obtained by Monquero et al. (2012) and Costa et al. (2010a) for the herbicides tested here, in which the esthetic beauty and the green color of the grass were retained, and full recovery occurred before 35 DAA.

Differences in plant height between the treatments occurred only from 21 DAA. In this period, only the herbicide 2.4-D inhibited growth in the plants of the chemical treatments tested, but it did not cause toxic symptoms in plants, as shown in Table 1. After 28 and 35 DAA, a greater height was detected in plants treated with 2.4-D in both treatment periods, which differed from the control; after 35 DAA, none of the herbicides tested inhibited the growth of plants, and growth stimulation was observed for those treated with 2.4-D. Moreover, time differences were observed for the oxadiazon and 2.4-D treatments, which differed from the control treatment (Figure 1). 
Table 1. Symptoms of poisoning (\%) observed in Zoysia japonica (Emerald grass) submitted to the application of herbicides. Botucatu-SP, 2009.

\begin{tabular}{lcccccc}
\hline \multirow{2}{*}{ Treatments } & $\begin{array}{c}\text { Doses } \\
\text { (g a.i./a.e. } \mathbf{h a}^{-1} \text { ) }\end{array}$ & $\mathbf{7}$ & $\mathbf{1 4}$ & $\mathbf{2 1}$ & $\mathbf{2 8}$ & $\mathbf{3 5}$ \\
\cline { 3 - 7 } & - & $0.00(0.00) \mathrm{d}$ & $0.00(0.00) \mathrm{b}$ & $0.00(0.00)$ & $0.00(0.00)$ & $0.00(0.00)$ \\
Control & 720 & $1.00(4.88) \mathrm{c}$ & $0.00(0.00 \mathrm{~b}$ & $0.00(0.00)$ & $0.00(0.00)$ & $0.00(0.00)$ \\
Bentazon & 50 & $2.75(9.53) \mathrm{b}$ & $4.25(11.78) \mathrm{a}$ & $0.00(0.00)$ & $0.00(0.00)$ & $0.00(0.00)$ \\
Nicosulfuron & 112.5 & $0.00(0.00) \mathrm{d}$ & $0.00(0.00) \mathrm{b}$ & $0.00(0.00$ & $0.00(0.00)$ & $0.00(0.00)$ \\
Halosulfuron & 875 & $7.50(15.75) \mathrm{a}$ & $3.25(10.25) \mathrm{a}$ & $0.50(2.85)$ & $0.00(0.00)$ & $0.00(0.00)$ \\
Oxadiazon & 698 & $0.00(0.00) \mathrm{d}$ & $0.50(2.03) \mathrm{b}$ & $0.00(0.00)$ & $0.00(0.00)$ & $0.00(0.00)$ \\
2.4-D & & $56.38^{* *}$ & $29.17^{* *}$ & $3.00^{\text {ns }}$ & - & - \\
\hline F treatment & & 34.5 & 50.7 & 282.8 & - & - \\
C.V. (\%) & & 0.15 & 0.18 & 0.12 & - & - \\
Standard error & & 3.89 & 4.57 & 3.01 & - & - \\
D.M.S. & & &
\end{tabular}

The means followed by the same letter in the column do not differ statistically according to Tukey's test $(\mathrm{p} \leq 0.05)$; percentage data $(\%)$ were transformed into arcsine $\sqrt{ } \mathrm{x} / 100$, and their values are in parentheses.

-**: significant at $1 \%$ probability

- ns: not significant.

Figure 1. Height of Zoysia japonica (Emerald grass) submitted to the application of herbicides. Botucatu-SP, 2009.

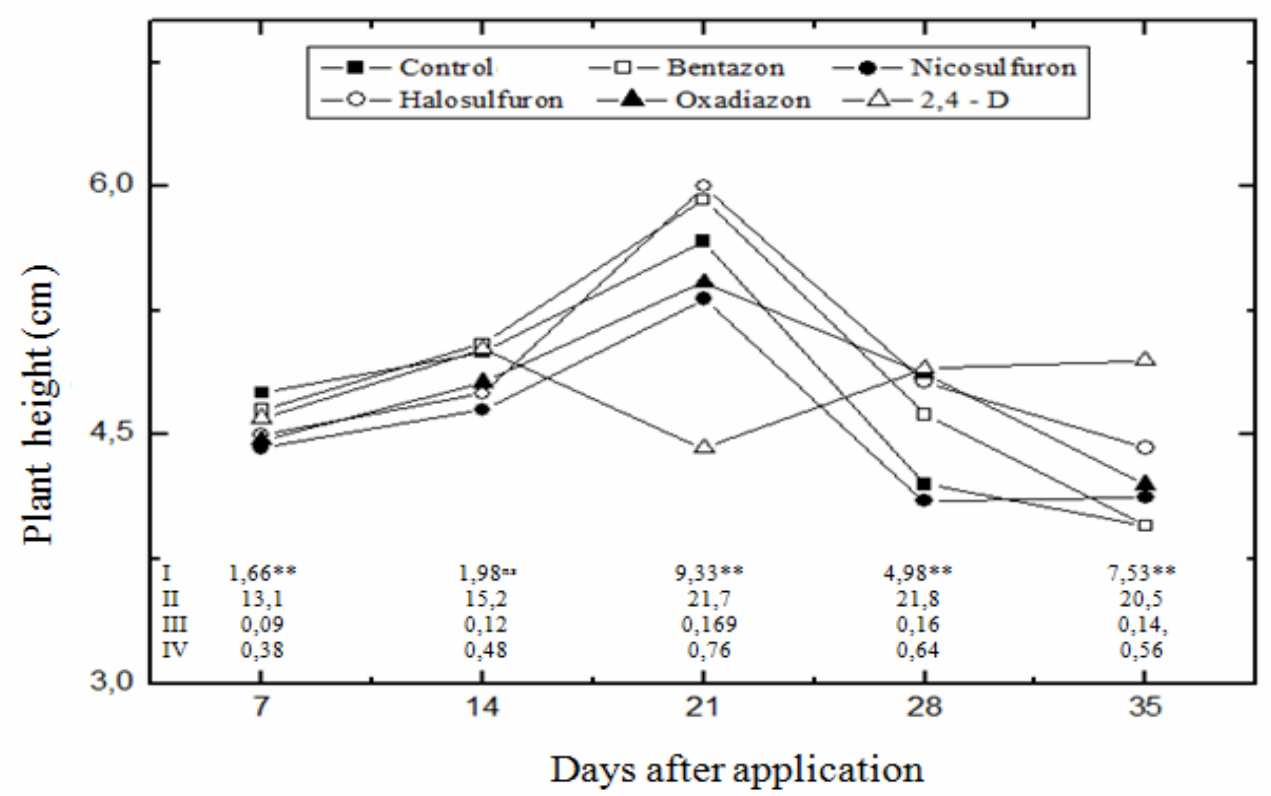

I: F treatment; II: C.V. (\%); III: Standard error; IV: D.M.S.

***: significant at $1 \%$ probability

-ns: not significant.

The growth stimulation observed in the plants treated with 2.4-D, a synthetic auxin, can be related to rapid inactivation of the herbicide molecule by the conjugation mechanism carried by monocots (TAIZ; ZEIGER, 2013). In addition, auxin herbicides are well known examples of chemicals, which increase growth at non-toxic concentrations or in tolerant species, imitating the natural auxin (ALLENDER, 1997). 
The reduction in height of the emerald grass at the end of this review study was due to the formation of new shoots, which were not prevented by the application of herbicides. Costa et al. (2010b) found that 2.4-D and bentazon caused height reductions in $Z$. japonica but did not consider this reduction a problem for the visual aspect of this species.
The changes in height promoted by these grass herbicides are reflected in the dry matter production of the plant (Table 2) because they showed similar values to the control treatment. Thus, the lack of differences observed in the gram dry weight may be related to the recovery from the injury caused by the herbicides through the growth of new shoots.

Table 2. Dry mass (g) of Zoysia japonica (Emerald grass) shoots submitted to the application of herbicides. Botucatu, 2009.

\begin{tabular}{lcc}
\hline \multicolumn{1}{c}{ Treatments } & Doses $\left(\mathbf{g}\right.$ a.i./a.e. ha $\left.^{-1}\right)$ & Dry mass (grams) \\
\hline Control & - & $29.75(5.50)$ \\
Bentazon & 720 & $15.25(4.00)$ \\
Nicosulfuron & 50 & $25.50(5.00)$ \\
Halosulfuron & 112.5 & $25.75(5.00)$ \\
Oxadiazon & 875 & $21.50(4.50)$ \\
2.4-D & 698 & $28.50(5.50)$ \\
\hline F treatment & & $0.68^{\mathrm{ns}}$ \\
C.V. (\%) & & 24.0 \\
Standard error & & 0.59 \\
D.M.S. & & 2.64 \\
\hline
\end{tabular}

Weight data were transformed into $\sqrt{x}+1.0$, and their values are in parentheses.

- ns: not significant.

Costa et al. (2010b) state that after metabolizing the herbicides, energy reserves become rapidly available for the restoration of normal development in Z. japonica. This is a compensatory effect of the accumulation of biomass after the disappearance of injuries; moreover, it emphasizes the importance of further studies to identify and describe the physiological mechanisms involved in the detoxification processes of herbicides in plants. The anatomical studies of the cross section of the leaf blade stand out as an important technique in the identification and description of anatomical structures that can influence the absorption and effect of herbicides, as well as assist in the description of the external and internal morphology of leaf structures. Thus, foliar anatomical approaches to plants can not only contribute information on the leaf structure that may be related to the differential penetration of products applied onto the leaves of plants (TUFFI SANTOS et al., 2006; COSTA et al., 2010 b) but also allow the identification of species as tolerant or resistant to a particular chemical, thus setting its selectivity (COSTA et al., 2006).

Figure 2 shows each cross section of the leaf blade of $Z$. japonica subjected to the herbicide $35 \mathrm{DAA}$, in which we can observe the absence of changes in the leaf cells of this species, which is confirmed by the resulting cluster analysis dendrogram (Figure 3). The cross section of the $Z$. japonica blade corroborates the description given by Carmen-Silva et al. (2009) and Costa et al. (2010b). 
Figure 2. Cross sections of the leaf blade of Zoysia japonica. Bf: Sheath of the Vascular Bundle. Cb: bulliform cells. EAB: epidermis of abaxial surface. DL: epidermis of the adaxial surface. Esc: Sclerenchyma. Fl: phloem. Par: parenchyma. Xi: Xylem. A, B, C, D, E, F, G: the keel region (central vein). H: wing region (portion between the center rib and the edge of the blade), A, B and C: control. D: bentazon, E: nicosulfuron, F: halosulfuron, G: oxadiazon $\mathrm{H}$ : 2.4-D. Bar = 100 micrometers (A, B, C, D, E, F, G). Bar = 50 mm (M). Botucatu, 2009.

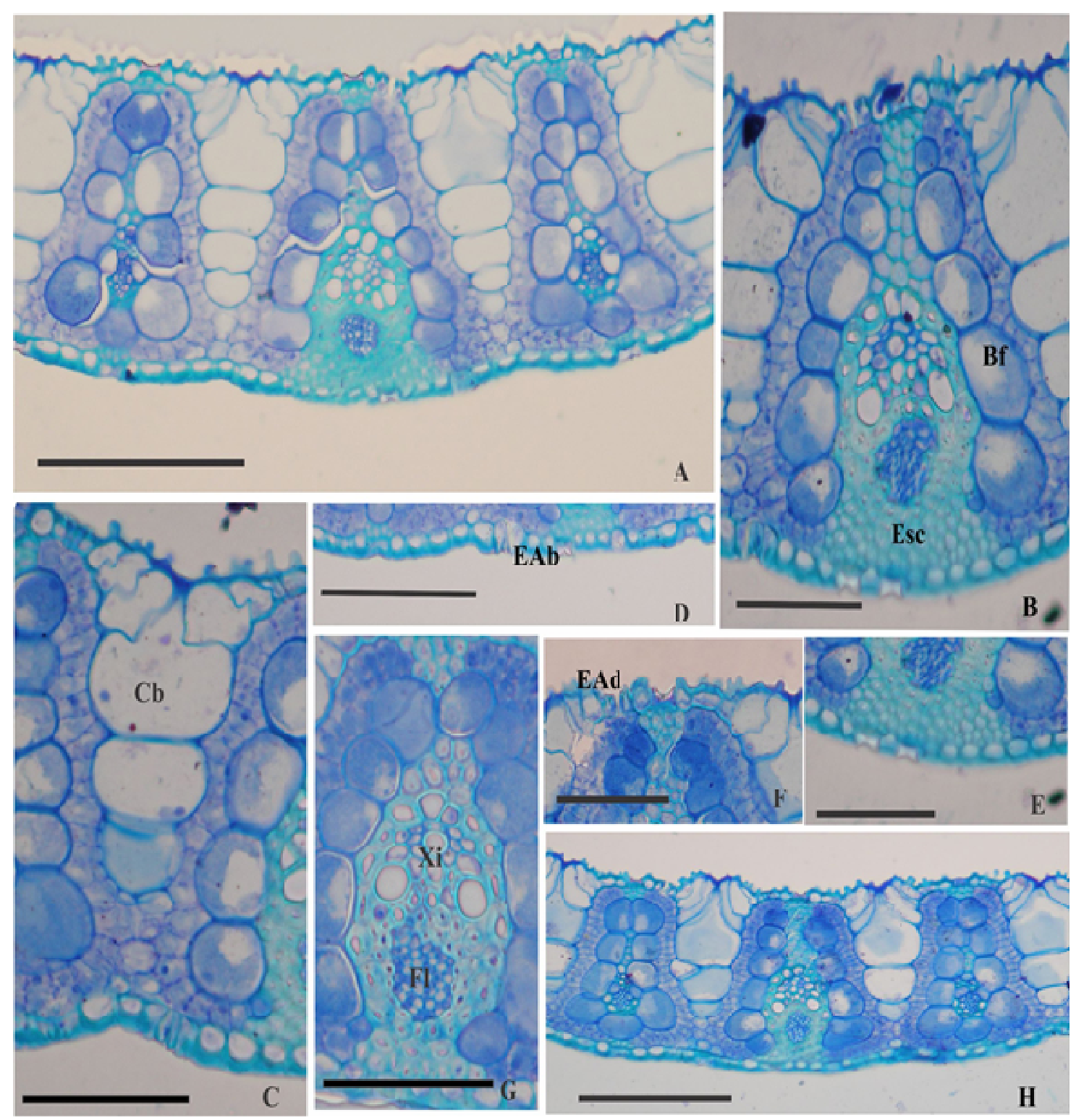

With the results of this study, it is thus possible to infer that the high tolerance of this species to the tested herbicides can be related to its compact mesophyll with few intercellular spaces, the sclerenchymatous caps on both sides of the vascular bundles, and the discontinuity of the sheath outside the abaxial portion of the larger bundle as the discontinuity of the outer sheath to the bundle, a large portion of pericycle, and the format and extent of bulliform cells. Such anatomical features can disrupt and reduce the mobility of the herbicides in the tissue, thus conferring increased tolerance of the species to herbicides, as can be observed throughout this work. 
Figure 3. Dendrogram resulting from the cluster analysis of 15 quantitative anatomical leaf characters, using the Euclidean distance average between the herbicides applied on Zoysia japonica 35 days after herbicide application. Botucatu-SP, 2009.

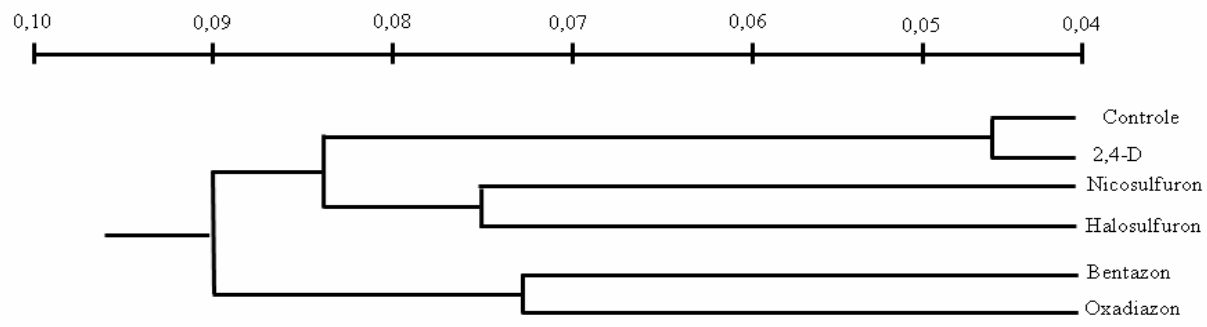

At 35 DAA, symptoms of intoxication were not observed in Z. japonica (Table 1), and no significant differences were observed in the anatomical leaf characters in the keel area (Table 3). However, as shown in Tables 4 and 5, in the wing area, it is possible to observe differences in the percentage of epidermal adaxial parenchyma. In the epidermis of the adaxial surface, the control treatment differed from the nicosulfuron, oxadiazon and 2.4D treatments. Parenchyma differences occurred between bentazon, nicosulfuron and oxadiazon, but these, in turn, did not differ from the other treatments or the control. It is noteworthy that the distance between the vascular bundles (wing) is not a variable that can be affected by herbicide application and is inherent in each species; however, translocation influences the speed of herbicide movement because the closer the proximity of the vascular bundles is, the faster the herbicide will move inside the plant.

Table 3. Average values of quantitative leaf anatomical characters of the midrib region (keel) of Zoysia japonica 35 days after herbicide application. Botucatu-SP, 2009.

\begin{tabular}{|c|c|c|c|c|c|c|c|}
\hline \multirow{2}{*}{ Treatments } & \multirow{2}{*}{$\begin{array}{c}\text { Doses } \\
(\mathrm{g} \text { a.i./a.e. } \\
\left.\text { ha }^{-1}\right)\end{array}$} & \multicolumn{6}{|c|}{ Anatomical characters of the keel region (\%) } \\
\hline & & EAd & EAb & SCL & BF & FV & PAR \\
\hline Control & - & $12.37(20.50)$ & $7.26(15.25)$ & $3.25(10.25)$ & $21.87(27,50)$ & $11.18(19,50)$ & $44.07(41.75)$ \\
\hline Bentazon & 720 & $12.51(20.75)$ & $6.67(15.00)$ & $3.94(11.75)$ & $25.21(30,00)$ & $11.78(20,00)$ & $39.87(39.25)$ \\
\hline Nicosulfuron & 50 & $12.78(20.75)$ & $7.35(15.50)$ & $3.27(10.50)$ & $25.39(30,25)$ & $10.82(19,00)$ & $40.39(39.50)$ \\
\hline Halosulfuron & 112,5 & $12.78(20.75)$ & $8.77(17.00)$ & $3.47(10.50)$ & $25.34(30,00)$ & $10.54(18,75)$ & $39.09(38.75)$ \\
\hline Oxadiazon & 875 & $14.09(22.00)$ & $6.86(15.25)$ & $3.84(11.25)$ & $25.74(30,50)$ & $11.86(20,25)$ & $37.61(37.50)$ \\
\hline $2,4-\mathrm{D}$ & 698 & $12.61(21.00)$ & $7.32(15.75)$ & $3.05(9.75)$ & $24.64(29,75)$ & $10.70(19,25)$ & $41.70(40.50)$ \\
\hline F tratamento & & $0.31^{\mathrm{ns}}$ & $1.06^{\mathrm{ns}}$ & $1.13^{\mathrm{ns}}$ & $0.68^{\mathrm{ns}}$ & $1.26^{\mathrm{ns}}$ & $1.16^{\mathrm{ns}}$ \\
\hline C.V. (\%) & & 9.2 & 9.0 & 12.7 & 8.9 & 5.3 & 6.5 \\
\hline Erro Padrão & & 0.96 & 0.70 & 0.85 & 1.32 & 0.52 & 1.29 \\
\hline D.M.S. & & 4.34 & 3.14 & 3.04 & 5.94 & 2.32 & 5.83 \\
\hline
\end{tabular}

EAD = epidermis of the adaxial surface $\mathbf{E A B}=$ epidermis of abaxial surface; $\mathbf{E S C}=$ Sclerenchyma; $\mathbf{B F}=$ Vascular Bundle Sheath; $\mathbf{F V}=$ Vascular Bundle; PAR = parenchyma

The means followed by the same letter in the column do not differ statistically according to Tukey's test $(\mathrm{p} \leq 0.05)$; percentage data $(\%)$ were transformed into arcsine $\sqrt{\mathrm{X}} / 100$, and their values are in parentheses.

- ns: not significant. 
The quantitative leaf anatomical results of $Z$. japonica reveal the tolerance of this species to the herbicides applied, with little change observed in the analyzed tissues compared to the control treatment.

The results of the leaf anatomical characters of Emerald grass indicate that none of the herbicides exclusively affected any leaf anatomical character, but the $Z$. japonica plants were less sensitive to the herbicides tested compared to the control treatment because they show little change in leaf anatomy and corroborate our intoxication, plant height and dry mass results.

The results listed in Tables 3, 4 and 5 were used to create the dendrogram (Figure 3 ) resulting from the cluster analysis of the average values of the leaf anatomical characteristics of Z. japonica 35 DAA. This can be observed in the formation of a single group at the level of 0.09 in the distance scale of similarity, which corroborates the results listed in Tables 1 and 3 and Figure 1 showing the high tolerance of this species to herbicides.

Table 4. Average values of quantitative leaf anatomical characters of the portion between the midrib and the edge of the blade (wing) of Zoysia japonica 35 days after herbicide application. Botucatu-SP, 2009.

\begin{tabular}{|c|c|c|c|c|c|}
\hline \multirow{2}{*}{ Treatments } & \multirow{2}{*}{$\begin{array}{c}\text { Doses } \\
\text { (g a.i./a.e. } \text { ha }^{-1} \text { ) }\end{array}$} & \multicolumn{4}{|c|}{ Anatomical characters of Wing Region } \\
\hline & & $\mathrm{ST}(\mu \mathrm{m})$ & DB $(\mu \mathrm{m})$ & BN & EAd (\%) \\
\hline Control & - & 106.18 & 101.41 & $11.00(3.00)$ & $17.29(24.50) \mathrm{a}$ \\
\hline Bentazon & 720 & 101.17 & 98.38 & $11.00(3.00)$ & $15.81(23.25) \mathrm{ab}$ \\
\hline Nicosulfuron & 50 & 100.59 & 96.08 & $11.00(3.00)$ & $13.57(21.50) b c$ \\
\hline Halosulfuron & 112.5 & 95.72 & 96.08 & $11.75(3.25)$ & 14.09 (22.00) abc \\
\hline Oxadiazon & 875 & 107.12 & 97.66 & $11.00(3.00)$ & $12.28(20.50) \mathrm{c}$ \\
\hline 2.4-D & 698 & 109.26 & 103.74 & $10.75(3.00)$ & $16.10(16.50) \mathrm{d}$ \\
\hline F treatment & & $1.60^{\mathrm{ns}}$ & $0.54^{\mathrm{ns}}$ & $1.00^{\mathrm{ns}}$ & $22.24 * *$ \\
\hline C.V. $(\%)$ & & 7.6 & 8.5 & 6.7 & 5.5 \\
\hline Standard error & & 3.90 & 4.18 & 0.10 & 0.59 \\
\hline D.M.S. & & 17.56 & 18.81 & 0.6 & 2.63 \\
\hline
\end{tabular}

$\mathbf{S T}=$ sheet thickness $\mathbf{D F}=$ Distance Between bundles; $\mathbf{N F}=$ Bundle number; $\mathbf{E A D}=$ epidermis of the adaxial surface; The means followed by the same letter in the column do not differ statistically according to Tukey's test $(p \leq 0.05)$;

Percentage data $(\%)$ were transformed into arcsine $\sqrt{x} / 100$, and their values are in parentheses.

The count data were transformed into $\sqrt{\mathrm{x}}+1.0$, and their values are in parentheses.

-**: significant at $1 \%$ probability

- ns: not significant. 
Table 5. Average values of quantitative leaf anatomical characters of the portion between the midrib and the edge of the blade (wing) of Zoysia japonica 35 days after herbicide application. Botucatu-SP, 2009.

\begin{tabular}{|c|c|c|c|c|c|c|c|}
\hline \multirow{2}{*}{ Treatments } & \multirow{2}{*}{$\begin{array}{c}\text { Doses } \\
\text { (g a.i./a.e. } \text { ha }^{-1} \text { ) }\end{array}$} & \multicolumn{6}{|c|}{ Anatomical characters of Wing Region } \\
\hline & & $\mathbf{E A b}(\%)$ & SCL (\%) & BF (\%) & FV $(\%)$ & PAR (\%) & \\
\hline Control & - & $8.30(16.75)$ & $2.30(8.25)$ & $25.01(29.75)$ & $9.59(18.00)$ & $37.50(37.75) \mathrm{ab}$ & \\
\hline Bentazon & 720 & $8.49(16.75)$ & $2.33(9.00)$ & $27.02(31.00)$ & $10.29(18.50)$ & $36.06(36.75) b$ & \\
\hline Nicosulfuron & 50 & $7.59(15.75)$ & $2.03(8.00)$ & $26.06(30.75)$ & $9.50(18.00)$ & $41.25(40.00) \mathrm{a}$ & \\
\hline Halosulfuron & 112.5 & $8.07(16.50)$ & $2.45(9.00)$ & $26.53(31.25)$ & $10.45(19.00)$ & $38.41(38.25) \mathrm{ab}$ & \\
\hline Oxadiazon & 875 & $7.92(16.50)$ & $2.51(8.75)$ & $26.56(31.00)$ & $10.48(18.75)$ & $40.46(39.25) \mathrm{a}$ & \\
\hline 2.4-D & 698 & $8.30(16.50)$ & $2.32(8.75)$ & $26.60(31.00)$ & $9.25(17.75)$ & $37.43(37.75) \mathrm{ab}$ & \\
\hline F treatment & & $0.33^{\mathrm{ns}}$ & $0.34^{\mathrm{ns}}$ & $1.44^{\mathrm{ns}}$ & $2.05^{\mathrm{ns}}$ & $4.50 * *$ & \\
\hline C.V. $(\%)$ & & 7.8 & 16.4 & 2.9 & 3.7 & 2.9 & \\
\hline Standard error & & 0.63 & 0.79 & 0.44 & 0.34 & 0.55 & \\
\hline D.M.S. & & 2.87 & 3.19 & 2.00 & 1.54 & 2.47 & \\
\hline
\end{tabular}

$\mathbf{E A B}=$ epidermis of abaxial; $\mathbf{S C L}=$ Sclerenchyma; $\mathbf{B F}=$ Vascular Bundle Sheath; $\mathbf{B V}=$ Vascular Bundle; $\mathbf{P A R}=$ parenchyma . The means followed by the same letter in the column do not differ statistically according to Tukey's test $(\mathrm{p} \leq 0.05)^{\prime}$ percentage data $(\%)$ were transformed into arcsine $\sqrt{ } \mathrm{x} / 100$, and their values are in parentheses.

The count data were transformed into $\sqrt{\mathrm{x}}+1.0$, and their values are in parentheses.

- **: significant at $1 \%$ probability

- ns: not significant.

Herbicidal selectivity studies on grass species in Brazil are still very relevant because the herbicide industries do not maintain research lines directed toward this market. Evidence of this is the tiny amount of scientific papers published by Brazilian researchers. The results presented here are encouraging for the use of these herbicides in lawn areas formed by Z. japonica.

The quantitative leaf anatomical results of $Z$. japonica reveal the tolerance of this species to the herbicides applied, with little change observed in the analyzed tissues compared to the control treatment.

The results of the leaf anatomical characters of Emerald grass indicate that none of the herbicides exclusively affected any leaf anatomical character, but the $Z$. japonica plants were less sensitive to the herbicides tested compared to the control treatment because they show little change in leaf anatomy and corroborate our intoxication, plant height and dry mass results.

Herbicidal selectivity studies on grass species in Brazil are still very relevant because the herbicide industries do not maintain research lines directed toward this market. Evidence of this is the tiny amount of scientific papers published by Brazilian researchers. The results presented here are encouraging for the use of these herbicides in lawn areas formed by Z. japonica.

\section{Conclusions}

1. The tested herbicides are selective for $Z$. japonica so that the herbicide symptoms disappear after 21 DAA, and the species is fully recovered after this period without any damage to the lawn.

2. The discontinuity of the outer sheath to the bundle, a large portion of the pericycle and the format and extent of the bulliform cells of the $Z$. japonica leaf blade can confer the tolerance to herbicides observed in this species.

\section{References}

ALLENDER, W. J. Effect of trifluoperazine and verapamil on herbicide stimulated growth of cotton. Journal of Plant Nutrition, New York, v. 20, n. 1, p. 6980, 1997.

BHOWMIK, P. C. Introduction to the symposium: history of sulfonylurea herbicide use in turfgrass environments. 
Weed Technology, Champaign, v. 26, n. 3, p. 575-578, 2012.

BROSNAN, J. T.; ARMEL, G. R.; KLINGEMAN, W. E.; BREEDEN, G. K.; VARGAS, J. J.; FLANAGAN, P. C. Selective star-of-Bethlehem control with sulfentrazone and mixtures of mesotrione and topramezone with bromoxynil and bentazon in cool-season turfgrass. Hort Technology, Alexandria, v. 20, n. 2, p. 315-318, 2010.

CARMO-SILVA, A. E. Grasses of different C4 subtypes reveal leaf traits related to drought tolerance in their natural habitats: changes in structure, water potential, and amino acid content. American Journal of Botany, Columbus, v. 96, n. 7, p. 1222-1235, 2009.

CHRISTOFFOLETI, P. J.; ARANDA, A. N. Seletividade de herbicidas a cinco tipos de gramas. Planta Daninha, Viçosa, MG, v. 19, n. 2, p. 273-278, 2001.

COSTA, N. V.; MARTINS, D.; RODRIGUES, A. C. P.; CARDOSO, L. A. Seletividade de herbicidas aplicados na grama Batatais e na grama São Carlos. Planta Daninha, Viçosa, $M G$, v. 28, n. 2, p. 365-374, 2010a.

. Seletividade de herbicidas aplicados nas gramas Santo Agostinho e Esmeralda. Planta Daninha, Viçosa, MG, v. 28, n. 1, p. 139-148, 2010 b.

COSTA, N. V.; RODEllA, R. A.; MARTINS, D. Diferenciação de espécies daninhas aquáticas pela análise multivariada de caracteres estruturais foliares. Planta Daninha, Viçosa, MG, v. 24, n. 1, p. 13-20, 2006.

GERRITS, P. O. The application of glycol metacrylate in histotechnology: same fundamental principles. Gröningen: Leica Gmgh, 1991. 80 p.

GODOY, L. J. G. BÔAS, R. L. V.; BACKES, C.; LIMA, C. P. Doses de nitrogênio e potássio na produção de grama esmeralda. Ciência e Agrotecnologia, Lavras, v. 31, n. 5, p. 1326-1332, 2007.

GROSSMAN, K. Auxin herbicides: current status of mechanism and mode of action. Pest Management Science, Sussex, v. 66, n. 2, p. 113-120, 2009.

JOHANSEN, D. A. Plant microtechnique. New York: McGraw-Hill, 1940. 523 p.

KOJOROSKI-SILVA, C. M.; SCHEFFER-BASSO, S. M.; CARNEIRO, C. M.; GUARIENTI, M. Desenvolvimento morfológico das gramas Esmeralda, São Carlos e Tifton 419. Ciência e Agrotecnologia, Lavras, v. 35, n. 3, p. 471-477, 2011.
MACIEL, C. D. G.; POLETINE, J. P.; RAIMONDI, M. A.; RODRIGUES, M.; RIBEIRO, R. B.; COSTA, R. S.; MAIO, R. M. D. Desenvolvimento de gramados submetidos à aplicação de retardadores de crescimento em diferentes condições de luminosidade. Planta Daninha, Viçosa, MG, v. 29, n. 2, p. 383-395, 2011.

MAPA/AGROFIT. Sistema de agrotóxicos fitossanitários. Coordenação-Geral de agrotóxicos e afins. Brasília: MAPA, 2015. Disponível em: <http://agrofit.agricultura. gov.br/agrofit_cons/principal_agrofit_cons $>$. Acesso em: 21 out. 2015.

MCELROY, J. S.; MARTINS, D. Use of herbicides on turfgrass. Planta Daninha, Viçosa, MG, v. 31, n. 2, p. 455-467, 2013.

METCALFE, C. R. Anatomy of the monocotyledons. Oxford: Clarendon Press, 1960. v. 1, 731 p.

MONQUERO, P. A. Seletividade de herbicidas em espécies de gramas ornamentais. Revista Brasileira de Herbicidas, Maringá, v. 11, n. 3, p. 296-304, 2012.

O'BRIEN, T. P.; FEDER, N.; McCULLY, M. E. Polychmofic staing of plant cellular wall by toluidine blue. Protoplasma, New York, v. 59, n. 2, p. 368-373, 1964.

PIMENTEL-GOMES, F. Curso de estatística experimental. 6. ed. Piracicaba: Gráfica Binetti, 1976. $430 \mathrm{p}$.

ROHLF, F. J. NTSYS- $p c$ : numerical taxonomy and multivariate analysis system version 1.7. New York: Exeter Publication, 1992. 410 p.

SNEATH, P. H. A.; SOKAL, R. R. Numeral taxonomy. San Francisco: W. H. Freemam, 1973. 50 p.

SOCIEDADE BRASILEIRA DA CIÊNCIA DAS PLANTAS DANINHAS. Procedimentos para instalação, avaliação e análise de experimentos com herbicidas. Londrina: SBCPD, 1995. v. 1, 42 p.

SOUZA, J. R.; PERECIN, D.; AZANIA, C. A. M.; SCHIAVETTO, A. R.; PIZZO, I. V.; CANDIDO, L. S. Tolerância de cultivares de cana-de-açúcar a herbicidas aplicados em pós-emergência. Bragantia, Campinas, v.68, n. 4, p.941-951, 2009.

TAIZ, L.; ZEIGER, E. Fisiologia vegetal. 5. ed. Porto Alegre: Artmed, 2013. 954 p.

TUFFI SANTOS, L. D.; IAREMA, L.; THADEO, M.; FERREIRA, F. A.; MEIRA, R. M. S. A. Características da epiderme foliar de eucalipto e seu envolvimento com a tolerância ao glyphosate. Planta Daninha, Viçosa, MG, v. 24, n. 3, p. 513-520, 2006. 
